\title{
Political Intervention in Debt Contracts
}

\section{Patrick Bolton and Howard Rosenthal}

Princeton University

This paper develops a dynamic general equilibrium model of an agricultural economy in which poor farmers borrow from rich farmers. Because output is stochastic (we allow for idiosyncratic and aggregate shocks), there may be default ex post. We compare equilibria with and without political intervention. Intervention takes the form of a moratorium and is decided by voting. When bad economic shocks are highly likely, state-contingent debt moratoria always improve ex post efficiency and may also improve ex ante efficiency. Moreover, the threat of moratoria enhances efficiency. When adverse macro shocks are unlikely, state-contingent moratoria always improve ex ante welfare by completing incomplete debt contracts.

\section{Introduction}

Motivation.-In the last quarter of the eighteenth century and the first half of the nineteenth, many American states passed laws that provided

We wish to thank John Cochrane and two referees for very helpful comments. We are also grateful to Eric Berglof, Denis Gromb, Oliver Hart, Susanne Lohmann, Marco Pagano, Gerard Roland, Ernst-Ludwig von Thadden, and especially Thomas Palfrey and Tano Santos for extensive comments and Keith Poole for literature directions on the history of bankruptcy. We thank participants in seminars at Berkeley, Caltech, Stanford, the Center for Advanced Study in the Behavioral Sciences, European Centre for Advanced Research in Economics, Harvard, State University of New York at Binghamton, the University of British Columbia, the University of Cape Town, the University of Washington, the National Bureau of Economic Research, the Lake Arrowhead conference on the Political Economy of Bankruptcy, and the Inter-American Development Bank and OECD conference "Institutional Arrangements to Ensure Willingness to Repay in Financial Markets" for comments. This paper was written while Rosenthal was a Fellow at the Center for Advanced Study in the Behavioral Sciences. He is grateful for financial support provided by National Science Foundation grant SBR-9022192. We thank Kelly Chang and Dov Rothman for research assistance and Kathleen Much for editing.

[Journal of Political Economy, 2002, vol. 110, no. 5]

(C) 2002 by The University of Chicago. All rights reserved. 0022-3808/2002/11005-0001\$10.00 
for debt moratoria (Rothbard 1962; Domowitz and Tamer 1997). During the Great Depression, states passed laws for debt moratoria of farm mortgages (Alston 1983, 1984; Rucker and Alston 1987). Moreover, the Franklin Roosevelt administration devalued the dollar against gold. Devaluation would have triggered gold clauses present in almost $\$ 100$ billion of private debt and most likely would have led to a wave of corporate bankruptcies. Congress, however, abrogated all gold payment clauses, relieving debtors of $\$ 69$ billion of additional payments generated by the devaluation (Kroszner 1998). In recent times, bankrupt industrial firms and financial institutions have been the beneficiaries of bailouts or government takeovers. In this paper, we present a model of ex post political intervention in private debt contracts in a democracy.

Failure results from either firm-specific or macroeconomic factors. When there is an exceptionally large downturn, individuals in financial distress may be sufficiently numerous that they have the political power to enact legislation that protects debtors against foreclosure. Such ex post political intervention can serve as a correction for incomplete contracts and a remedy for possible externalities arising when there are many simultaneous failures. Debt contracts are highly incomplete and are typically not contingent on macroeconomic shocks. For example, in the interwar period, farmers' repayment obligations were in nominal terms even though agricultural prices were falling (Alston 1983). Ex post political intervention to reduce debt obligations in exceptionally harsh economic circumstances may be a way of completing these incomplete contracts. On the other hand, the efficient functioning of credit markets might be impaired were creditors to anticipate that downturns would lead to intervention. Allowing for ex post intervention may influence interest rates and the volume of lending ex ante. Thus the question arises whether there are net benefits to having political institutions that permit ex post intervention.

Basic model and main results.-We address this question in a threeperiod model in which debt contracts must be concluded in the presence of two types of uncertainty. One concerns the productive capacity of the individual borrower. The other concerns an aggregate shock that occurs while the debt contract is outstanding. We characterize equilibria in our economy both when there is no possibility of ex post intervention and when debt moratoria can be declared by a vote of the citizens.

We refer to a moratorium as any form of debt cancellation or rescheduling. For simplicity, we model political intervention as a direct vote of the citizens. This model should be seen as a simplification of a representative democracy in which politicians respond to public opinion as events unfold. That is, legislatures enact laws that respond to the changing demands of the electorate. The nature of these events may not be immediately apparent at a local level, but legislatures may be 
able to respond to global changes by aggregating dispersed local information. In other words, when there is aggregate uncertainty, majority voting can, in the absence of verifiable economic data, "certify" when there are bad times that warrant debt relief.

We consider an extremely simplified economy composed only of farmers and rentiers. Rich farmers (or rentiers) can lend to poor farmers. Alternatively, rich farmers can hire them as agricultural laborers. In the equilibrium without political intervention we focus on, credit markets are open at date 0 . At date 1 , when output on individual farms is realized, all poor farmers who have low output default on their debt obligations. These farmers are foreclosed and have no choice but to become laborers. There may be further investment at date 1 , but there can be no further lending since threats to foreclose in the last period have no bite. (This is a convenient artifact of our three-period model structure.)

The equilibrium without political intervention involves two important inefficiencies. The first is that defaulting poor farmers may be displaced from land on which they can be more productive than under their new occupation. The second is that nondefaulting poor farmers are liquidity constrained and cannot invest as much as is desirable on their land.

We find that unanticipated political intervention mitigates these two ex post inefficiencies. It also creates an important pecuniary externality in the agricultural labor market at date 1: by giving defaulting poor farmers the option to remain on their land, political intervention increases the equilibrium price of labor.

This pecuniary externality drives the model by inducing preferences of a pivotal voting bloc among the solvent poor farmers to change in response to aggregate shocks. A critical assumption is that both the mean and variance in individual farm outputs are positively correlated with the aggregate shock. Thus, when the economy is in a good state, solvent poor farmers have more means to expand production by hiring labor. At the same time there is an ample supply of defaulting farmers to provide cheap labor, unless, of course, there is political intervention. Since political intervention increases the price of labor, the solvent poor farmers oppose it. On the other hand, in a bad state the scope for expansion of solvent poor farmers may be so small that the advantages of cheap labor do not offset the direct benefit of debt relief. Because of this change in political preferences, actual political intervention will be state-contingent if the solvent poor farmers are politically decisive.

Anticipated intervention, as one might expect, has ambiguous ex ante effects. Anticipated moratoria tend to undermine the date 0 credit market. If bad states are much more likely than good states, credit markets can be preserved by a complete ban on political intervention or, equivalently, by a supermajority requirement large enough to block intervention. When, in contrast, good states are much more likely than bad 
states, ex ante lending will not be discouraged if lenders anticipate that intervention will occur only in bad states. The appropriate supermajority requirement in this case would block intervention only in good states.

Alternatively, intervention can be discouraged by ex ante lending limits, such as usury laws. Such limitations would give solvent poor farmers enough retained earnings for expansion that they would oppose intervention. ${ }^{1}$ For some parameter constellations these limits can, surprisingly, improve the allocation of resources in the first period.

The Panic of 1819.-The empirical motivation for the model we developed comes from our observation that state legislatures in the United States frequently voted for debt moratoria. Most notably, many states intervened in private debt contracts as a result of the severe downturn known as the Panic of 1819. States either passed stay laws imposing moratoria, made it more difficult to seize debtor assets, or made it more difficult to sell debtor assets at auction (Rothbard 1962, pp. 196-97). At the same time, the federal government allowed its borrowers to delay repayments of land debts.

The major cause of the Panic, according to North (1961, pp. 182-83), was the collapse of the world price for cotton. ${ }^{2}$ Between January 1818 and June 1819, cotton prices fell more than 50 percent. Cotton, in turn, dominated both American exports and the economy of the South. The decline of cotton prices also affected the West since the West's economy was largely driven by sales of wheat and livestock to the South. Bulk commodities were transported to the South by river. The Northeast provided nonbulk manufactured goods, banking, shipping, and other services to the West and South. ${ }^{3}$

Both the South and the West correspond roughly to the technological structure of our model. The West and western portions of the South were 99 percent rural in 1820. The Atlantic seaboard portion of the South was 95 percent rural. What little urban population existed was mainly in the New England (10.5 percent urban) and Middle Atlantic

\footnotetext{
${ }^{1}$ See Epple and Spatt (1986) for a similar justification of lending restrictions on local debt. Glaeser and Scheinkman (1998) also motivate usury laws as a form of social insurance when there is incomplete contracting with regard to future income flows. Their individuals are uncertain whether they will be debtors or creditors. In contrast, in our model, citizens can favor usury laws even when they know they will be creditors. They favor usury laws as a means of thwarting political intervention that would cause a collapse of the credit market.

${ }^{2}$ An alternative explanation for the Panic was a sharp contraction in the money supply resulting from policies of the privately owned Second Bank of the United States (see, e.g., Freehling 1966, p. 26). This alternative explanation would also be consistent with the exogenous shock required by our model.

${ }^{3}$ We follow Douglass North's specification of the South as Alabama, Georgia, Louisiana, Mississippi, North Carolina, South Carolina, and Virginia; the West as Illinois, Indiana, Kentucky, Missouri, Ohio, and Tennessee; and the Northeast as Connecticut, Delaware, Maine, Maryland, Massachusetts, New Hampshire, New Jersey, New York, Pennsylvania, and Rhode Island.
} 
(11.3 percent) states. More than two-thirds of the labor force worked on farms (U.S. Department of Commerce 1975, p. 134). Given the low technological level of agriculture at the time, it is not too far-fetched to regard the South and West as single-commodity regions with labor as the major input factor.

Commodity prices are made endogenous when new land is brought into cultivation. Some of the drop in the cotton price reflects an expansion in production from 157,000 bales in 1812 to 377,000 in 1821 . But over a longer run, cotton production was able to expand tremendously while whites prospered in the "Cotton Kingdom." By 1859, 5,337,000 bales were produced (U.S. Department of Commerce 1975, p. 518). Clearly the world market price was also determined by shifts in foreign demand. World price shocks bear similarity to the macroeconomic shock in our model.

An important omission from our model is a market for land. ${ }^{4}$ Federal government land sales boomed with rising prices for cotton and other sources of prosperity at the end of the Napoleonic Wars. Receipts from sales in the South increased from $\$ 332,000$ in 1815 to $\$ 9,063,000$ in 1818. In the West, they jumped from $\$ 2,078,000$ to $\$ 4,556,000$ (North 1961, p. 256). With the Panic, land sales fell abruptly, never regaining the 1818 level in the South. The receipts were in large part only down payments, some of which had been borrowed privately. ${ }^{5}$ Thus many citizens in the South and West were debtors to the federal government, with payments due on the outstanding balance of land purchases. Before the passage of the Land Act of 1821, the federal government was owed some $\$ 23,000,000$ (Rohrbough 1968). The land debt to the government exceeded annual federal expenditures $(\$ 20,000,000$ in 1820 [U.S. Department of Commerce 1975, p. 1104]) and was an appreciable fraction of the government debt of $\$ 90,000,000$ in 1821 (p. 1103).

The pressure for debtor relief led to legislation mainly in frontier states. We specify the frontier as Ohio, Indiana, Illinois, Kentucky, Tennessee, Missouri, Alabama, Mississippi, and Louisiana. Six of the nine frontier states were listed by Rothbard (1962) as providing some form

\footnotetext{
${ }^{4}$ In particular, political intervention may affect the equilibrium price of land as well as labor. There is no market for land in our model because we consider an economy in which land is abundant but wheat and labor are relatively scarce. A model with a market for land would be more realistic, but the basic economics of the more elaborate model would be essentially the same as in our simpler setup.

${ }^{5}$ As there is no market for land in our model, our story does not quite fit these events. It would be innocuous, however, to introduce a market for land. At date 0 all this would mean is a higher investment outlay for farmers; as for date 1, default will give rise to excess supply of land and consequently to a collapse of property prices as seen in the Panic of 1819; the main complication with introducing land in our model is the possibility of strategic behavior by rich buyers in the market for land, such as waiting for panics to buy land on the cheap. It is beyond the scope of this paper to address these somewhat peripheral issues.
} 
of debtor relief in response to the Panic. In contrast, only four of the remaining 15 states passed a "stay law" or some other measure. ${ }^{6}$

Because the great preponderance of new agricultural investment was taking place in frontier states, distressed debtors were likely to be more dominant in the population in these states than in the older states. In addition, land prices were likely to have fallen more. ${ }^{7}$

Also, frontier states were likely to have universal male suffrage rather than suffrage restricted on the basis of property holding or wealth. ${ }^{8}$ It is thus not surprising that most of the ex post intervention occurred on the frontier. None of the frontier states had substantial property or taxpaying requirements for voting. ${ }^{9}$ In contrast, 10 of the 15 nonfrontier states had firm requirements for either property ownership or taxpaying. Only two of these 10 states with suffrage restrictions passed a debtor relief measure as against eight of the 14 states without restrictions. ${ }^{10}$

Note, moreover, that debt relief was largely a northern and border state matter. Of the eight southern states, only Louisiana and Tennessee, both on the frontier, granted debt relief. The absence of debt relief in the old South may be the expression of a reaction in the South to previous intervention by state legislatures. Also, at the time of the Panic, state legislatures in the South were dominated by property owners, the high endowment types in our model. ${ }^{11}$

Thus suffrage and apportionment may be an important part of the story of why stay laws and other forms of debt relief were more prevalent in frontier states. Not only may a larger fraction of the population have

${ }^{6}$ The $\chi^{2}$ statistic is $\chi_{1}^{2}=3.70$, and the $p$-value is .05 . This $\chi^{2}$ statistic and those later refer to $2 \times 2$ contingency tables such as [frontier, nonfrontier] $\times$ [law, no law]

${ }^{7}$ Most of the available data on the Panic of 1819 are political. Unfortunately, there do not appear to be economic data of private defaults before 1830, as Domowitz and Tamer (1997) have pointed out. On the other hand, there are ample data on political outcomes, which can be informative about preferences of economic agents and their reaction to macro shocks.

${ }^{8}$ Of course, suffrage requirements would become endogenous in an extended version of our model. We can only speculate that, during the transition from colonial status to democracy, creditors or property owners dominated the political process and opted to protect their interests from redistribution. In contrast, on the frontier, yeoman farmersdebtors were likely to have had more weight when state voting requirements were adopted upon entry to the United States.

${ }^{9}$ Unimportant requirements were found in Ohio, Tennessee, Louisiana, and Mississippi. In these states, most adult white males would have qualified for a waiver. We thank Alexander Keyssar of Duke University, who has generously made available to us his detailed compilation of suffrage requirements (see Keyssar 2000).

${ }^{10}$ The $\chi^{2}$ statistic is $\chi_{1}^{2}=3.53$, and the $p$-value is .06 .

${ }^{11}$ Within the South, one white man, one vote applied only in the four frontier states (Freehling 1990, p. 164). In Virginia, about half the white males were disenfranchised by a property requirement. Moreover, the legislature was not reapportioned to reflect greater population growth beyond the Tidewater (pp. 169-70). South Carolina had universal white male suffrage but severe property qualifications for office holding; the state senate was malapportioned to give control to the older coastal region (p. 222). 
been in default in those states, but also debtors may have had more political voice there.

The remainder of the paper is organized as follows: Section II outlines the model. Section III considers the economy without political intervention. Section IV allows for intervention in the form of debt moratoria. Finally, Section V offers concluding comments and directions for further research.

\section{The Model}

We begin by setting up an economy with no political institutions that permit ex post intervention. The only institutions in this economy are courts that costlessly enforce debt contracts. To model debt and default, we require three periods: $t=0,1,2$. At $t=0$, borrowing, lending, and investment take place. At $t=1$, a first set of production flows is realized. Borrowers repay or default. In the case of default, lenders make a continuation or liquidation decision. At the end of period 1, some defaulting borrowers may become laborers and enter into labor contracts for production at $t=2$. At $t=2$, a second set of production flows is realized. All accumulated production is consumed.

\section{A. Technology, Preferences, and Markets}

To keep things as simple as possible, we consider a one-commodity economy in which, to fix ideas, the commodity is wheat. To produce wheat, farmers need labor and wheat. On any given farm there can be at most two wheat crops, one at $t=1$ and the other at $t=2$.

\section{Preferences and Endowments}

All farmers are assumed to have identical risk-neutral preferences. Risk neutrality is assumed for technical convenience. It is worth pointing out, however, that risk neutrality combined with limited liability induces behavior, contracting arrangements, and qualitative features similar to risk aversion. Also for simplicity we assume that all consumption takes place at the end of the second period. The objective of each farmer is then particularly simple: maximize expected lifetime wealth.

We assume that there are $M-N$ poor farmers and $N$ wealthy farmers or rentiers. The wealthy have a per capita endowment of wheat of $\bar{W}>1 .{ }^{12}$ The poor have an endowment of zero. We assume that the poor

\footnotetext{
${ }^{12}$ If $\bar{W}<1$ and there are no rentiers, then there is no scope for lending since wealthy farmers are better off investing everything in their own farms.
} 
are substantially more numerous than the wealthy. Specifically, $M>$ $N(1+\bar{W}) .^{13}$

\section{Technology and Information}

The production function on any given farm is given by

$$
x^{t}=\theta^{v} f\left(k^{t-1},\left(1+l^{t-1}\right)\right),
$$

where $x^{t}$ is the output of wheat in period $t ; \theta^{v}$ is a farmer-specific productivity shock (it can be interpreted as either farmer ability or fertility of the farmer's plot of land), which varies with macroeconomic state $v=H, L ; k^{t-1}$ is the amount of wheat invested in period $t-1\left(k^{t-1}\right.$ could also be thought of as the amount of cleared land on the farm); and $1+l^{t-1}$ is the quantity of labor employed on the farm in period $t-1$; it includes the farmer's labor plus the labor from $l^{t-1}$ workers.

Note that the only relevant productivity parameter here is the farmer's type. Laborers' types are irrelevant. This feature of the production function captures in a stark way the idea that what matters foremost for farm productivity is the organizational and entrepreneurial talent of the farmer. We assume that once wheat is invested, it is "sunk" on the farm and can neither be converted back to consumption nor transferred to another farm.

Again to keep things as simple as possible, we consider the following Leontief production function:

$$
\begin{gathered}
\theta^{v} f\left(k^{t-1},\left(1+l^{t-1}\right)\right)= \\
\begin{cases}\theta^{v}\left(\min \left[k^{t-1}, 1+l^{t-1}\right]\right) & \text { for } k^{t-1} \leq \bar{k}, \text { where } \bar{k}>1 \\
\theta^{v}\left(\min \left[\bar{k}, 1+l^{t-1}\right]\right) & \text { for } k^{t-1}>\bar{k} .\end{cases}
\end{gathered}
$$

Thus the maximum possible wheat production for an individual farm is $\theta^{v} \bar{k}$. This production function was chosen to model a competitive agricultural economy. And to obtain strictly positive profits in equilibrium, we need at least one scarce factor (here it will be wheat) and diminishing marginal productivity with respect to one of the more abundant factors. Labor has no marginal productivity when it exceeds capital on a farm. ${ }^{14}$

Our production function also exhibits decreasing (or, more precisely, no) returns to scale beyond the level of wheat investment $\bar{k}>1$, so that

\footnotetext{
${ }^{13}$ This assumption guarantees not only that the poor will always be a majority of the voters but also that the poor will have excess demand for loans. If the poor are a majority but the inequality above is not satisfied, there can be excess supply of loans.

${ }^{14}$ In Bolton and Rosenthal (2001), we explore an alternative model in which labor in excess of capital has strictly positive marginal productivity. In that model, laborers always earn strictly positive wages. Here we assume that (indifferent) workers work for zero wages.
} 
there is no benefit to investing more than $\bar{k}$ on a farm. As will become clear below, it is essential to have some form of decreasing returns to scale to limit rich farmers' demand for agricultural laborers.

The farmer-specific productivity shocks, $\theta^{v}$, in state $v$ are independently, identically distributed and take the values $0 \leq \theta_{b}^{v}<\theta_{a}^{v}<\theta_{g}^{v}$ with probabilities $m_{b}, m_{a}$, and $m_{g} \equiv 1-m_{a}-m_{b} \cdot{ }^{15}$ In the equilibrium we solve for, the good types $\theta_{g}^{v}$ always remain solvent, the bad types $\theta_{b}^{v}$ always become insolvent if they have borrowed wheat to invest, and the average types $\theta_{a}^{v}$ become insolvent only in state $L$ when there is an unfavorable macroeconomic shock.

We assume that poor farmers do not know their type at $t=0$; they are all equally ignorant about their talents and expect an average productivity in state $v$ of $\bar{\theta}^{v}=m_{b} \theta_{b}^{v}+m_{a} \theta_{a}^{v}+m_{g} \theta_{g}^{v}$. That is, not only can lenders not screen borrowers according to type, but borrowers cannot use information about their own types in deciding whether to borrow. At $t=1$, poor farmers do learn their individual types, but this information remains private to the farmer. We also assume that the total population of poor farmers is large enough that the proportions of poor farmer types in the population are approximately the same as the probabilities $m_{a}, m_{b}$, and $m_{g}$.

The common "macroeconomic" shock (say, weather conditions or the market price of wheat) shifts the values of the poor farmers' farm-specific shocks. We assume that state $H$ occurs with probability $\lambda$ and $L$ with probability $1-\lambda$. We assume that the productivity shocks are such that $\theta_{g}^{H}>\theta_{g}^{L}>\theta_{a}^{H}>\theta_{a}^{L}>1>\theta_{b}^{H}>\theta_{b}^{L}$. Note that since $\theta_{b}^{v}<1$, the bad types will never make additional investments at $t=1$. For simplicity we assume that rich farmers have equally fertile land. Their productivity is denoted $\phi^{v}$. Their average expected productivity exceeds that on poor farms: $\phi=\lambda \phi^{H}+(1-\lambda) \phi^{L} \geq \lambda \bar{\theta}^{H}+(1-\lambda) \bar{\theta}^{L} .^{16}$

The production function and productivity shocks completely describe the technological structure of our economy.

\section{Contracts and Markets}

In this simple economy there can be at most two markets: one for credit and another for labor. Because at $t=0$ only rich farmers have endowments, any wage contracts will involve rich farmers' hiring poor ones. Rich farmers face the following decision at $t=0$ : Should they use their wheat to hire poor farmers as laborers, or should they invest it, either in lending to poor farmers or in adding capital to their own farms?

\footnotetext{
${ }^{15}$ As will become clear below, we need at least three types of farmers to model different rates of default for different realizations of the macroeconomic shock.

${ }^{16}$ In Bolton and Rosenthal (2001), we explore an alternative model in which all farmers are ex ante identical in all respects except for the initial endowment of wheat.
} 
Reciprocally, poor farmers have the following occupational choice decision: Should they borrow and remain independent farmers, or should they become laborers?

Although both markets could be open at $t=0$, we demonstrate the existence of an equilibrium with only credit transactions. Such situations arise when all poor farmers prefer to borrow and work on their own farm rather than work as agricultural laborers, and all rich farmers prefer to lend than to hire workers at the prevailing equilibrium market terms. At $t=1$, the same two markets might be open. But, as we shall explain, only the agricultural labor market is open at this interim stage.

The type of credit and labor contracts that can be written is constrained by what the courts can enforce. We make the following assumptions about the enforceability of these contracts.

Credit contracts. - Loans can be made in wheat to another farmer in exchange for repayment at date 1 . We assume that the macroeconomic shock is not describable in a contract or verifiable by the courts, so that the repayment cannot be conditioned on the realization of the shock. In addition, wheat output on any given farm is not observable, let alone verifiable. These two assumptions imply that a debt contract can be only the borrower's promise to make a unit repayment of $D$ at $t=1$ and the debtor's right to foreclose part or all of the farm in case of default (see Bolton and Scharfstein 1990, 1996; Hart and Moore 1994, 1998). ${ }^{17}$

We assume that at $t=1$ it is not legally possible for a farmer to acquire some other piece of land and continue to produce there unless he has repaid his debts. Thus by foreclosing on the debtor's land, a creditor can prevent the debtor from continuing production. This threat of foreclosure will induce the farmer to repay his debts when he can. Otherwise he would lose the second-period output of his farm. The unit repayment $D$ at date 1 is therefore like the purchase by the debtor of the right to continue producing wheat on the land. Because there is no production beyond $t=2$, there is no incentive for the borrower to repay a loan at that date. In anticipation, the creditor will insist that repayments take place only at date 1 . If the debtor does not produce enough wheat to repay $D$, he may be forced to default and the creditor may foreclose. At that point the debtor simply runs away with what wheat he has and becomes an agricultural laborer.

In practice, defaulted farmers might have the option of beginning again elsewhere on the frontier rather than becoming laborers. The basic properties of our model will hold, however, as long as continuing

\footnotetext{
${ }^{17}$ To keep things simple, we consider only complete foreclosure here. It may be optimal to allow for partial foreclosure in response to partial default, but this would significantly complicate the analysis and exposition. All the qualitative predictions of our model would continue to hold if we extended the analysis to the case of partial foreclosure, albeit in a less extreme form.
} 
on the original farm is valuable relative to moving on and there is increased labor supply from some defaulted farmers. The substantial political pressures for debt relief reveal a strong preference for not moving elsewhere.

Since at the time of repayment the borrower and (possibly) the lender can infer the realization of the aggregate shock $v=H, L$ (by observing the realizations on their own farm), it may be mutually beneficial for them to lower $D$ in state $L$ and thus reduce the risk of a costly default. As will become clear below, the equilibria we characterize are such that there is no gain to renegotiating the debt contract in state $L$ and allowing the debtor to stay and produce on his land. We consider two alternative scenarios: one in which the aggregate shock $v=H, L$ is revealed only to the debtor (this is the case in which the creditor is a rentier) and the other in which both contracting parties learn $v=H, L$ (this happens when the lender is a rich farmer). Under each scenario the equilibrium debt contract will be renegotiation-proof, but the implications of political intervention in each case are different.

Employment contracts.-Just as with debt contracts, there is an enforceability issue with labor contracts. We make wage contracts enforceable by requiring a simultaneous exchange of work hours for wages. Laborers are paid when, figuratively, the seeds are sown or the soil tilled. That is, they are paid before output is realized.

At this point, we have fully described the economy with no political institutions. As we shall see, such an economy will give rise to a particularly high rate of insolvency at date 1 if the economy has a bad macro shock. This outcome reflects the contractual incompleteness of debt contracts, which precludes state-contingent repayments. To overcome this inefficiency, the citizens in this economy may be willing to set up political institutions that can intervene ex post to suspend, delay, or cancel debt repayments. Because political decisions are made ex post, after the macro shock is realized and the individual farmer types are learned, political institutions can serve as a mechanism to remedy the contractual incompleteness of debt contracts. A potential drawback of such institutions, however, is that they may undermine the proper enforcement of debt contracts ex post.

\section{B. Political Institutions}

The political institution we consider is voting on debt moratoria. ${ }^{18}$ The vote takes place at $t=1$, after production is realized but before debt repayment or default takes place. We avoid the complications of rep-

\footnotetext{
${ }^{18}$ See, however, Bolton and Rosenthal (2001) for an analysis of another form of intervention through bailouts.
} 
resentative democracy and restrict consideration to direct democracy. We do consider restricting the franchise by giving voting rights to farmers but not to laborers. We also investigate the implications of requiring majorities larger than a simple majority to enact debt relief measures.

Moratoria have adverse selection problems. Because a farmer's wheat production is private information, even good farmers may choose not to repay during a moratorium. Consequently, alternative institutions that reduce adverse selection might be preferable. Specifically, individual debtors might be able to apply to an independent authority, say a bankruptcy court, for leniency. The bankruptcy court would be able to learn, at a cost, the type of the debtor and the macro shock. Repayment would be adjusted to the realization of the macro shock. Bankruptcy courts were notoriously costly mechanisms in the nineteenth century (Balleisen 1996) and remain somewhat so today. In any event, we defer analysis of bankruptcy and other institutions for future research.

In addition to investigating equilibrium under moratoria and the base case of no political intervention, we compare the relative efficiency of the institutions. This comparison would suggest what institution might be chosen ex ante, behind a "veil of ignorance," where endowments, productivity types, and the macro shock are all unknown. We also consider institutional choice at an interim level in which endowments are known but the productivity and macro shocks are not.

\section{The Economy without Political Intervention}

All equilibria in this agrarian economy have an open labor market at $t=1$. Demand for agricultural labor comes from wealthy farms (if there are any) or from type $\theta_{g}$ poor farms. Supply comes from insolvent poor farmers. The credit market at $t=1$, on the other hand, is always shut. The reason is that since all production ends at $t=2$, creditors are left without a liquidation threat to enforce repayment of debt in the final period. $^{19}$

While continuation equilibria at $t=1$ are all rather similar, equilibria at $t=0$ may differ substantially in terms of occupational choice outcomes of poor farmers. When only rich farmers can lend wheat, then

\footnotetext{
${ }^{19}$ As we already noted, this is a convenient artifact of our three-period model structure. In a more general model with, say, an infinite number of periods, credit markets would always be open. The main substantive difference with our model in such a setup would be that creditors' threat to foreclose in the event of default would have less force since they would have an interest in continuation. Also, borrowers are likely to default only following a string of bad outcomes in such a model, since they may be able to roll over their debts. If aggregate shocks take the form of protracted slumps and booms, equilibria are likely to exhibit the same qualitative patterns of defaults as in our three-period model. The benefits of political intervention in such a model are also likely to be qualitatively the same.
} 
one equilibrium at $t=0$ may be such that no credit is extended to poor farmers at all. In that equilibrium, poor farmers can work only as agricultural laborers on wealthy farms. In a less extreme equilibrium at $t=0$, some poor farmers work as agricultural laborers and others borrow wheat to invest on their own farms. In that equilibrium, poor farmers are indifferent between working as agricultural laborers and taking on debt. Finally, a third equilibrium may obtain in which all poor farmers become debtors and no one works as an agricultural laborer.

We emphasize the third equilibrium since, as we show below, it generates the highest per capita output. We consider two extreme cases. In the simpler one, all $N$ wealthy agents are rentiers and lend $\bar{W}$ to the $M-N$ poor farmers, who each borrow $k_{p}=N \bar{W} /(M-N)<1 .{ }^{20}$ In the more complicated case, the $N$ wealthy agents are rich farmers who invest one on their own farms and lend the remainder $\bar{W}-1$ to poor farmers, who now can borrow only $k_{p}=N(\bar{W}-1) /(M-N)<1$. We restrict attention to parameter values such that equilibrium debt repayments $D^{*}$ specified at $t=0$ induce default by both bad and average types in state $L$, but only bad types in state $H$. Defaulting farmers are foreclosed and are pushed onto the agricultural labor market. For further simplicity we restrict attention to parameter values such that there is excess supply of labor at $t=1$ under all contingencies, so that all agricultural laborers have no choice but to work at an equilibrium subsistence wage, which we normalize to zero.

To determine the conditions under which an equilibrium with these characteristics obtains, it is helpful to begin by characterizing first the continuation equilibrium in each state at $t=1$.

\section{A. Date 1 Continuation Equilibrium}

We begin by considering poor farmers.

Poor farmers' ex post default decisions.-All poor farmers have borrowed an amount $k_{p}$ at $t=0$ for a repayment $D^{*} k_{p}$ at $t=1$. In state $L$, good farmers can repay their loans if and only if $\theta_{g}^{L} \geq D^{*}$, and average and bad farmers cannot repay if $D^{*}>\theta_{a}^{L}$. Similarly, in state $H$, good and average farmers can repay their loans if and only if $\theta_{a}^{H} \geq D^{*}$, and bad farmers cannot repay if $D^{*}>\theta_{b}^{H}$. The highest repayment rate $D^{*}$ inducing these state-contingent defaults is thus $D^{*}=\theta_{a}^{H}$. We shall proceed under the assumption that this is the rate set at $t=0$ and later determine under what conditions this is indeed the equilibrium rate.

Good farmers' incentives to repay if $D^{*}=\theta_{a}^{H}$.-If a farmer of type $\theta_{g}$ defaults, he keeps the entire first-period output but earns nothing in the

\footnotetext{
${ }^{20}$ Note that we have $k_{p}<1$ given our assumption that poor farmers are sufficiently numerous.
} 
second period. The return from strategically defaulting is thus $\theta_{g}^{v} k_{p}$. Incentive compatibility then requires that type $\theta_{g}$ earn at least $\theta_{g}^{v} k_{p}$ over the two periods in each state $v=H, L$. For the repayment rate $\theta_{a}^{H}$, total earnings are greater than $\theta_{g}^{v} k_{p}$ because, after repayment, the good poor farmer has retained earnings of $\left(\theta_{g}^{v}-\theta_{a}^{H}\right) k_{p}>0$ at $t=1$ and obtains at least output $\theta_{g}^{v} k_{p}$ at $t=2$. Hence, a farmer of type $\theta_{g}$ always has a strict incentive to repay if he believes that the debt contract will be enforced and that creditors will refuse to renegotiate the contract at $t=1$.

Average and bad farmers' incentives to default.-A bad poor farmer's decision is simple. If $D^{*}=\theta_{a}^{H}$, he cannot repay and must default. As for average types, they cannot repay in state $L$ and are just able to meet the required repayment in state $H$. In the latter state they are indifferent between defaulting and not defaulting on the debt repayment since they get $\theta_{a}^{H} k_{p}$ regardless of what they decide to do. We assume that indifferent types honor their debt obligations.

Expected debt repayments.-The discussion above tells us that if $D^{*}=$ $\theta_{a}^{H}$ and there is no debt renegotiation, the expected debt repayment on a unit loan is given by

$$
G_{r}=\left[\lambda\left(m_{g}+m_{a}\right)+(1-\lambda) m_{g}\right] \theta_{a}^{H} .
$$

Since the rich will lend rather than just keep wheat for consumption only if $G_{r}>1$, we henceforth assume that the parameters on the righthand side above are large enough for $G_{r}>1$.

Debt renegotiation.-Debt contracts are expected to be enforced only when it is not in creditors' interest to forgive debt ex post. Consider first the case in which lenders are rentiers who do not observe the aggregate shock $v$ (recall that they do not know the true type of the farmer). These creditors will never forgive debt to $\theta_{b}^{H}$ or $\theta_{b}^{L}$ since $G_{r}>$ $1>\theta_{b}^{H}>\theta_{b}^{L}$. And a reduction from $D^{*}=\theta_{a}^{H}$ to $\theta_{a}^{L}$ is not in their interest at $t=1$ if

$$
G_{r} \geq\left(m_{g}+m_{a}\right) \theta_{a}^{L} .
$$

We shall henceforth assume that in the case in which lenders are rentiers, parameters are such that this condition is met. Consider now the case in which lenders are rich farmers who can infer $v$. They obviously will not renegotiate in state $H$. It is easy to verify that these creditors will also not accept any reduction in debt in state $L$ if and only if

$$
m_{g} \theta_{a}^{H} \geq \max \left\{\left(m_{g}+m_{a}\right) \theta_{a}^{L}, \theta_{b}^{L}\right\} .
$$

Again, we shall assume that in the case in which lenders are rich farmers, parameters are such that this condition is met. Then debt contracts specifying repayments $D^{*}=\theta_{a}^{H}$ are renegotiation-proof and result in 
foreclosure of defaulting poor farmers. We highlight this observation in the lemma below.

Lemma 1. When rentiers who do not observe $v$ at $t=1$ are lenders, debt contracts with repayments $D^{*}=\theta_{a}^{H}$ are renegotiation-proof if and only if

$$
\theta_{a}^{H} \geq \frac{\left(m_{g}+m_{a}\right) \theta_{a}^{L}}{\lambda\left(m_{g}+m_{a}\right)+(1-\lambda) m_{g}} .
$$

When rich farmers who can observe $v$ at $t=1$ are lenders, debt contracts with repayments $D^{*}=\theta_{a}^{H}$ are renegotiation-proof if and only if

$$
m_{g} \theta_{a}^{H} \geq \max \left\{\left(m_{g}+m_{a}\right) \theta_{a}^{L}, \theta_{b}^{L}\right\} .
$$

Proof. See the discussion above.

Having characterized poor farmers' default decisions, we now turn to solvent farmers' investment decisions at $t=1$.

Wealthy and good poor farmers' additional investments and demand for labor at $t=1$.-After default and foreclosure of poor farmers, $(M-$ $N)\left(m_{b}+m_{a}\right)$ agricultural laborers seek employment in state $L$ and $(M-N) m_{b}$ in state $H$. This newly available workforce allows solvent farmers to expand operations by increasing investment up to $\bar{k}$ and hiring up to $\bar{k}-1$ laborers on their farm. Good poor (type $\theta_{g}^{v}$ ) farmers have residual income $\left(\theta_{g}^{v}-\theta_{a}^{H}\right) k_{p}$ to expand their farming operations, and wealthy farmers have $\phi^{H}+(\bar{W}-1)\left(m_{g}+m_{a}\right) \theta_{a}^{H}$ in state $H$ and $\phi^{L}+(\bar{W}-1) m_{g} \theta_{a}^{H}$ in state $L$.

One can envision different equilibrium scenarios following default at $t=1$. They would vary by the amount of additional investment and agricultural employment that is feasible in solvent farms. As will become clear below, our analysis of political intervention in debt contracts is not dependent on any specific scenario materializing at $t=1$. To avoid repetition we shall focus on only one plausible scenario.

A. Good poor farmers are constrained in their additional investment by their residual income $\left(\theta_{g}^{v}-\theta_{a}^{H}\right) k_{p}$. Specifically, good poor farmers do not have enough liquidity to expand up to $\bar{k}$ in state $H$. And in state $L$, they cannot even expand to $k=1$ and have no demand for labor. This is the case in which parameter values are such that

$$
\left(\theta_{g}^{L}-\theta_{a}^{H}\right) k_{p} \leq 1-k_{p} \leq\left(\theta_{g}^{H}-\theta_{a}^{H}\right) k_{p} \leq \bar{k}-k_{p} .
$$

Under this assumption, the demand for labor from a good poor farmer is positive only in state $H$ and, given our technological assumptions, is given by

$$
\left(\theta_{g}^{H}-\theta_{a}^{H}\right) k_{p}-\left(1-k_{p}\right) .
$$

This term represents the amount of wheat left over for investment after 
the debt has been repaid and capital increased to one, the maximum efficient scale at which a farmer can operate without hiring any agricultural laborers (recall that laborers are hired at an equilibrium wage of zero).

B. Rich farmers (when lending at $t=0$ comes from wealthy farmers) expand their investment from $k=1$ at $t=0$ to $k=\bar{k}$ at $t=1$ in state $H$ but are constrained by their income to expand to only $k=1+$ $\phi^{L}+(\bar{W}-1) m_{g} \theta_{a}^{H}$ in state $L$. This is the case in which parameter values are such that ${ }^{21^{2}}$

$$
\phi^{L}+m_{g} \theta_{a}^{H}(\bar{W}-1) \leq \bar{k}-1 \leq \phi^{H}+\left(m_{g}+m_{a}\right) \theta_{a}^{H}(\bar{W}-1) .
$$

Under this scenario, in the rentier equilibrium, aggregate demand for labor in each state following default and foreclosure is given by

$$
\left[\left(\theta_{g}^{H}-\theta_{a}^{H}\right) k_{p}-\left(1-k_{p}\right)\right] m_{g}(M-N)
$$

in state $H$ and zero in state $L$.

In the equilibrium with rich farmers, on the other hand, aggregate demand for labor is the sum of good poor and wealthy farmers' demand

$$
\left[\left(\theta_{g}^{H}-\theta_{a}^{H}\right) k_{p}-\left(1-k_{p}\right)\right] m_{g}(M-N)+(\bar{k}-1) N
$$

in state $H$ and the demand of wealthy farmers

$$
\left[\phi^{L}+(\bar{W}-1) m_{a} \theta_{a}^{H}\right] N
$$

in state $L$. Thus there is excess supply of labor at $t=1$ under all contingencies (and an equilibrium subsistence wage of zero) in the rentier equilibrium if and only if

$$
m_{b}>\left[\left(\theta_{g}^{H}-\theta_{a}^{H}\right) k_{p}-\left(1-k_{p}\right)\right] m_{g} .
$$

And in the wealthy farmer equilibrium, an excess supply of labor at $t=1$ under all contingencies is obtained if and only if

$$
(M-N) m_{b}>(\bar{k}-1) N+\left[\left(\theta_{g}^{H}-\theta_{a}^{H}\right) k_{p}-\left(1-k_{p}\right)\right] m_{g}(M-N) .
$$

Conditions (8), (5), and (6) are necessary and sufficient to guarantee that following default and foreclosure there is an excess supply of agricultural labor in both rentier and wealthy farmer equilibria. We summarize our discussion in the lemma below.

LEMma 2. When condition (5) holds, the continuation equilibrium at $t=1$ is such that the following conditions hold:

\footnotetext{
${ }^{21}$ To keep things simple, we assume here that rich farmers have diversified their loan portfolio so that, conditional on the state, they get an (almost) sure return on their loans.
} 
A. In a rentier equilibrium (eq. [7] must also hold), (i) aggregate demand for labor is given by the demand of good poor farmers; it is limited by their aggregate residual income to

$$
(M-N) m_{g}\left[\left(\theta_{g}^{H}-\theta_{a}^{H}\right) k_{p}-\left(1-k_{p}\right)\right]
$$

in state $H$ and zero in state $L$; (ii) there is excess supply of labor.

B. In a wealthy farmer equilibrium (eqq. [6] and [8] must also hold), (i) both rich and good poor farmers have a demand for agricultural laborers in state $H$; aggregate demand is then

$$
\left[\left(\theta_{g}^{H}-\theta_{a}^{H}\right) k_{p}-\left(1-k_{p}\right)\right] m_{g}(M-N)+(\bar{k}-1) N ;
$$

(ii) only rich farmers demand labor in state $L$; their demand is then limited by their aggregate disposable income $N\left[\phi^{L}+m_{g} \theta_{a}^{H}(\bar{W}-\right.$ $1)$; and (iii) there is again excess supply of labor.

Proof. See the discussion above.

We later provide numerical examples in which the conditions of the lemma hold simultaneously.

This completes the characterization of the continuation equilibrium following default and foreclosure at $t=1$.

\section{B. Equilibrium at Date 0}

We now derive conditions under which all poor farmers become selfemployed farmers at $t=0$, borrowing an amount $k_{p}$ in exchange for a unit repayment $D^{*}=\theta_{a}^{H}$ at $t=1$.

Rentier equilibrium.-The lender's expected return at $t=0$ is maximized with a repayment $D^{*}=\theta_{a}^{H}$ if

$$
\begin{aligned}
\left(m_{g}+m_{a}\right) \theta_{a}^{L} & \leq G_{r}, \\
\max \left[m_{g} \lambda \theta_{g}^{H}, m_{g} \theta_{g}^{L}\right] & <G_{r}
\end{aligned}
$$

The second inequality guarantees that a repayment above $\theta_{a}^{H}$ reduces the lender's expected revenue. And our analysis of renegotiation establishes that a repayment lower than $\theta_{a}^{H}$ reduces expected revenues when the first inequality holds.

Now, if $G_{r} \geq 1$, rentiers are willing to lend all their wealth $\bar{W}$ for a repayment $D^{*}=\theta_{a}^{H}$. But under our assumptions there is then still excess demand for loans by poor farmers. Therefore, if $G_{r} \geq 1$ and conditions (9) hold, the unique symmetric rentier equilibrium at $t=0$ is for each farmer to borrow $k_{p}=N \bar{W} /(M-N)<1$ in return for a repayment $D^{*}=\theta_{a}^{H}$ at $t=1$.

Wealthy farmer equilibrium.-Characterization of equilibria with lending 
by wealthy farmers is more complex since poor farmers now also have an occupational choice decision: whether to borrow and be selfemployed or become agricultural laborers earning an equilibrium wage $w$. Our analysis of the continuation equilibrium at $t=1$ above shows that on each unit borrowed a poor farmer's ex ante net return from both date 1 and date 2 output is

$$
G_{p}=\left[\lambda \bar{\theta}^{H}+(1-\lambda) \bar{\theta}^{L}\right]+m_{g}\left[\lambda\left(\theta_{g}^{H}-\theta_{a}^{H}\right) \theta_{g}^{H}+(1-\lambda)\left(\theta_{g}^{L}-\theta_{a}^{H}\right) \theta_{g}^{L}\right] .
$$

The first term in this expression represents the expected first-period return on investment. The poor farmer can obtain at least this much by not repaying his loan in the first period. He may obtain more by repaying the loan in the first period if he turns out to be an average or good type. The second term represents the good poor farmer's gain from expanding output at $t=1$. Indeed, following repayment of debt $D^{*}=\theta_{a}^{H}$, the farmer has $\left(\theta_{g}^{v}-\theta_{a}^{H}\right) k_{p}$ available for investment, which he can use entirely to increase capital since labor is free. Since the poor borrow $k_{p}$ units of wheat, the total ex ante return of a poor farmer is given by $R_{p}=G_{p} k_{p}$.

Consider now rich farmers' lending decisions. They would never want to lend more than $\bar{W}-1$, because the marginal return on capital $k<$ 1 invested on their own farms is greater than the maximum feasible return on a loan, $\phi=\lambda \phi^{H}+(1-\lambda) \phi^{L}>G_{r}$. But they would not want to expand investment on their farm beyond $k=1$ and hire additional labor at $t=0$ if $G_{r} \geq \phi /(1+w)$, where the left-hand side is the payoff from lending one unit of wheat to a poor farmer and the right-hand side is the expected payoff from investing a unit on one's own farm and hiring agricultural labor at market wage $w$. In other words, rich farmers prefer to lend rather than invest if equilibrium wages in the agricultural labor market are too high or if $w \geq\left(\phi / G_{r}\right)-1$. To be able to hire any agricultural workers, a rich farmer must offer a wage such that a poor farmer prefers to be a laborer rather than a self-employed farmer, or $w \geq R_{p}$. Taking this constraint to be binding and substituting for $R_{p}$, we obtain the condition that a rich farmer prefers a credit contract to an employment contract if and only if

$$
k_{p} \geq \frac{\left(\phi / G_{r}\right)-1}{G_{p}} .
$$

When condition (10) holds, rich farmers are willing to lend $k_{p}=$ $N(\bar{W}-1) /(M-N)$ to each poor farmer at unit repayment rate $D^{*}=$ $\theta_{a}^{H}$. At that rate poor farmers would like to borrow more than $k_{p}$. In other words, there is excess demand for loans. Conditions (4) and (10) guarantee that $D^{*}=\theta_{a}^{H}$ is the equilibrium repayment at $t=0$.

We summarize this discussion in the following proposition. 
Proposition 1. When conditions (3), (5), (9), and (7) hold, there exists a unique symmetric rentier equilibrium at $t=0$ such that all poor farmers become self-employed and borrow $k_{p}=N \bar{W} /(M-N)$ from rich farmers in return for a repayment $D^{*}=\theta_{a}^{H}$ at $t=1$. Given this repayment, all type $\theta_{b}$ poor farmers default and their farms are foreclosed in both states at $t=1$, and all type $\theta_{a}$ farmers default in state $L$. Similarly, when conditions (4), (6), (8), (9), and (10) hold, there exists a wealthy farmer equilibrium at $t=0$ such that all poor farmers become selfemployed and borrow $k_{p}=N(\bar{W}-1) /(M-N)$ from rich farmers in return for a repayment $D^{*}=\theta_{a}^{H}$ at $t=1$. Given this repayment, all type $\theta_{b}$ poor farmers default and their farms are foreclosed in both states at $t=1$, and all type $\theta_{a}$ farmers default in state $L$.

Proof. See the discussion above.

\section{Other Equilibria}

In this subsection we complete our analysis by briefly considering other possible equilibria under lending by wealthy farmers. In the absence of political intervention, there are two other possible types of equilibria at $t=0$. In one, the credit market may shut down completely and poor farmers who work as agricultural laborers earn zero wages. In the other, which is "knife-edge," both credit and labor markets are open. We begin by characterizing the equilibrium with no lending.

Equilibrium with no lending.-This equilibrium can occur only when $\bar{k} \geq \bar{W}$. That is, endowments are below the point at which invested capital has zero marginal product. If the rich farmers decide to invest all their wheat on their own farms, there will be no wheat left to lend to poor farmers. If there is no lending to poor farmers, then there is excess supply of agricultural laborers (under our assumption that $M>N(1+$ $\bar{W})$ ), so that the equilibrium wage at $t=0$ is equal to zero.

At equilibrium wages of zero the rich always prefer to invest in their own farm rather than lend since the maximum expected gross unit return on lending is $G_{r}$, and the gross unit return on investing in their own farm is $\phi>G_{r}$. The poor farmers would, of course, prefer to borrow, but they are unable to obtain any financing.

Note that this equilibrium can coexist with the equilibrium we have considered so far, where all poor farmers become landowners by borrowing from the rich and do not work as agricultural laborers. They can coexist because equilibrium employment terms differ in each equilibrium. In the equilibrium with lending the implicit equilibrium wage at $t=0$ is $w \geq R_{p}$, whereas in the equilibrium with no lending the wage is zero.

A straightforward comparison of these equilibria shows that although total output at $t=1$ may be higher in the equilibrium with no lending 
(given that $\phi^{v}>\bar{\theta}^{v}$ ), at $t=2$ total output is always lower in state $H$ in the equilibrium with no lending since the wealthy produce at $\bar{k}$ in both equilibria but the good poor produce only in the lending equilibrium. For some parameter values the latter effect may be so large that ex ante expected output may be lower in the absence of lending. We also observe that rich farmers are better off ex ante in the equilibrium with no lending, whereas poor farmers obviously prefer the equilibrium with lending.

If $\bar{W}>\bar{k}$, the equilibrium with no lending unravels because rich farmers will want to lend their excess wheat. However, the no-lending equilibrium is approximated by an asymmetric equilibrium with credit rationing. In this type of equilibrium, at least $N(k-1)$ poor farmers must get no credit in order to produce excess labor and to allow wages to remain at zero, as in the no-lending equilibrium. The remaining handful of lucky poor farmers get credit. There is excess demand for credit, but no rich farmer has an incentive to lend more than $\bar{W}-\bar{k}$. Again this equilibrium is less efficient than the equilibrium in which the rich lend $\bar{W}-1 .{ }^{22}$

Equilibrium with both employment and lending.-As one might expect, a third, intermediate equilibrium, where both labor and credit markets are open at $t=0$, may also exist. In this equilibrium, rich farmers are indifferent between being lenders and being employers and poor farmers are indifferent between being landowners and being agricultural laborers. This knife-edge equilibrium exists both for $\bar{k} \geq \bar{W}$ and for $\bar{k}<\bar{W}$.

Proposition 2. When conditions (4), (6), (8), (9), and (10) hold, there may also exist two other wealthy farmer equilibria at $t=0$ : one such that all poor farmers become agricultural laborers and the other such that rich farmers are indifferent between lending and hiring agricultural laborers. In comparison to the equilibrium in which there are no agricultural laborers at $t=0$, in both equilibria, rich farmers are better off but poor farmers are worse off. These other equilibria will have lower output than the no-laborer equilibrium if the good poor are sufficiently productive at $t=2$.

Proof. See the discussion above.

\section{The Economy with Debt Moratoria}

The equilibrium without political intervention produces potentially massive defaults by average and bad poor farmers in state $L$. As several

\footnotetext{
${ }^{22}$ For the rationing equilibrium to hold with wages at zero, the per capita amount of wheat lent to the lucky poor must remain less than one. This requires that $N(\bar{W}-$ $\bar{k}) /[M-N(\bar{k}-1)] \leq 1$, which is guaranteed by our assumption that $M>N(1+\bar{W})$.
} 
historical episodes have revealed, when the number of defaults is large, political pressure builds to introduce some form of relief for the unfortunate. This relief can be in the form of additional subsidies or tax breaks; government guarantees on new loans or, possibly, even new government loans; bailouts; and finally debt moratoria.

Here we shall focus on moratoria. A moratorium is simply a form of debt cancellation and amounts to a direct ex post transfer from creditors to debtors.

Relief can be introduced if a "constitutionally" determined number of voters, denoted $\bar{M}$, support it. The relief granted is nonselective. That is, the relief cannot be conditioned on the productivity type of the farmer. All farmers can vote on whether to introduce some form of debt relief at $t=1$ following the realization of crops.

For economic efficiency, debt moratoria should be targeted only to certain types of farmers and should be limited to the amount of debt these farmers cannot repay. In practice, it is unfortunately difficult both to discriminate between different types of farmers and to limit the scope of debt forgiveness. Political support for a moratorium is maximized in our model by including all debtors in the scheme and by forgiving 100 percent of their debts. More precisely, any farmer who would vote for partial cancellation of the debt would prefer total cancellation to partial cancellation. Accordingly, we consider a vote on 100 percent debt relief for all poor farmers. ${ }^{23}$

\section{A. Ex Post Effects of Moratoria}

Winners and losers from a moratorium.-To see who will support such an initiative, we must first consider the effects of the moratorium on the labor market equilibrium at $t=1$. Obviously, bad poor farmers would always prefer to remain on their farm, if given a choice, rather than become agricultural laborers at the no-intervention wage of zero. Following a moratorium, they would stay out of the labor market unless wages increase beyond $\theta_{b}^{v} k_{p}$.

When equilibrium wages following a moratorium are $\theta_{b}^{v} k_{p}$, average farmers will not want to hire labor if $\theta_{a}^{v}<1+\theta_{b}^{v} k_{p}$. We make this simplifying assumption throughout this section. Good and rich farmers, however, want to hire laborers even at this higher wage. We shall suppose that the population of bad poor farmers is high enough to be able to

\footnotetext{
${ }^{23}$ Note, however, that moratoria in U.S. history have been limited in scope and time. Our analysis does not depend on the size of the moratorium in an essential way, except for the ex ante effects of anticipated moratoria. When moratoria are limited in size and scope, the ex ante equilibrium with moratoria is likely to be more efficient.
} 
meet the aggregate demand for labor at $t=1$ :

$$
m_{b}(M-N) \geq(\bar{k}-1) N+\left[m_{g}(M-N) \frac{\theta_{g}^{v} k_{p}-\left(1-k_{p}\right)}{1+\theta_{b}^{v} k_{p}}\right] .
$$

In this expression, the left-hand side is the mass of bad poor farmers. The right-hand side is the maximum demand for agricultural laborers by good poor and rich farmers.

Under this assumption, equilibrium wages following a moratorium will equal $\theta_{b}^{v} k_{p}$, a fraction of bad poor farmers will become laborers, and the remaining farmers will stay on their farms. Also, at that wage, all average poor farmers remain on their land. Thus the moratorium creates a positive pecuniary externality for bad and average poor farmers, who see their second-period wheat income net of investment increase from zero to, respectively, $\theta_{b}^{v} k_{p}$ and $\left(\theta_{a}^{v}\right)^{2} k_{p}{ }^{24}$ These farmers therefore clearly favor a moratorium. Note that this pecuniary externality arises at the expense of good poor and rich farmers..$^{25}$ Therefore, rich farmers would be opposed to this initiative even if the moratorium were limited to insolvent poor farmers (and therefore did not involve a direct loss in debt repayments). All rich farmers and rentiers would, a fortiori, be opposed to a moratorium that includes also solvent poor farmers.

Like their bad and average brethren, good poor farmers benefit from a moratorium by not repaying $D^{*} k_{p}=\theta_{a}^{H} k_{p}$ at $t=1$. However, like the rich farmers, they must pay higher wages following a moratorium. If the benefit in cheap labor outweighs the cost of repaying the loan, they will vote against the moratorium. That is, good poor farmers oppose a moratorium if

$$
\left(\theta_{g}^{v}-\theta_{a}^{H}\right) k_{p} \theta_{g}^{v} \geq \theta_{g}^{v}\left[\left(1-k_{p}\right)+\frac{\theta_{g}^{v} k_{p}-\left(1-k_{p}\right)}{1+\theta_{b}^{v} k_{p}}\right] .
$$

The left-hand side of (11) is the good poor farmer's gain from expanding output at $t=1$ under no moratorium. In this case the farmer has $\left(\theta_{g}^{v}-\theta_{a}^{H}\right) k_{p}$ available for investment, which he can use entirely to increase capital since labor is free. The right-hand side of (11) is his

\footnotetext{
${ }^{24}$ The income calculation for average poor farmers assumes $\theta_{a}^{v} k_{p}<1-k_{p}$. If this inequality does not hold, average poor farmers simply have $k=1$ at $t=1$.

${ }_{25}$ The pecuniary externality on wages is just one of several important pecuniary externalities that may be present. For tractability we focus on only one form of externality. But in practice, more important externalities may operate through the price of land, which is depressed when a large supply of foreclosed property is sold on the market. Also, there may be important demand externalities with a sharp fall in aggregate consumption (and therefore profits) following bankruptcy of an important fraction of the population.
} 
gain from expanding output under a moratorium. ${ }^{26}$ Then the farmer has a higher amount $\theta_{g}^{v} k_{p}$ available for investment, but he must now also spend $\theta_{b}^{v} k_{p}$ on each unit of agricultural labor he hires. Therefore, he can expand his farm only by

$$
\frac{\theta_{g}^{v} k_{p}-\left(1-k_{p}\right)}{1+\theta_{b}^{v} k_{p}}
$$

beyond $k=1$, so that the maximum increase in output under a moratorium is

$$
\theta_{g}^{v}\left[\left(1-k_{p}\right)+\frac{\theta_{g}^{v} k_{p}-\left(1-k_{p}\right)}{1+\theta_{b}^{v} k_{p}}\right] .
$$

In contrast, since the good poor demand no labor in state $L$, they clearly favor a moratorium in that state. We summarize this discussion in lemma 3 .

Lemma 3. Rich farmers or rentiers always oppose moratoria. Average and bad poor farmers always support moratoria. Good poor farmers are pivotal. They support a moratorium in state $L$ and oppose it in state $H$ if and only if condition (11) holds for $v=H$ but not for $v=L$.

Proof. See the discussion above.

Thus all poor farmers, who form a majority of voters, would vote in favor of a moratorium in state $L$. In state $H$, on the other hand, the poor farmers' coalition is divided. Therefore, it is possible that a sufficient majority in support of a moratorium may not materialize. We show below that a majority rule can be chosen ex ante so that a majority in favor of a moratorium arises only in state $L$.

Ex post efficiency of moratoria.-In the rentier case, an unanticipated moratorium obviously increases total output ex post since the bad poor continue to produce and the average and good poor not only continue to produce but also expand their farms to a size larger than would be possible were debts repaid. The same logic applies, slightly more subtly, to the wealthy farmer case. In state $H$, the wealthy expand to $\bar{k}$ regardless of repayment, so the increased output by the poor increases total output. In state $L$, the wealthy expand less if they are not repaid. As their repayments in state $L$ come solely from the good poor and the good poor expand, there is no loss in output as long as $\theta_{g}^{L} \geq \phi^{L}$. The general observation here is simply that the moratorium eliminates distortions of the real economy resulting from nominal debt obligations. In other words, moratoria improve ex post productive efficiency even though

\footnotetext{
${ }^{26}$ In general, condition (11) is more likely to be satisfied in state $H$. To see this, note that $k_{p}$ and $D^{*}=\theta_{a}^{H}$ are fixed, and assume $\theta_{b}^{H}=\theta_{b}^{L}$. Then the left-hand side increases faster than the right-hand side as $\theta_{g}^{v}$ increases. This effect is even stronger when $\theta_{b}^{H}>$ $\theta_{b}^{L}$.
} 
they lead to a redistribution from rich creditors to poor borrowers. ${ }^{27}$ Thus the main (potential) problem with moratoria is not ex post efficiency but ex ante efficiency, when moratoria are anticipated. Although this result is obvious, it is sufficiently important to be highlighted in the following proposition.

Proposition 3. Unanticipated moratoria always increase aggregate output (if $\theta_{g}^{L} \geq \phi^{L}$ ).

Proof. Obvious.

\section{B. Ex Ante Equilibrium with Anticipated Moratoria}

We shall restrict attention to parameter values such that a moratorium occurs only in state $L$. More precisely, we shall determine an equilibrium such that lenders and good poor farmers oppose a moratorium in state $H$, but all poor farmers favor a moratorium in state $L$. Then as long as

$$
M-N \geq \bar{M}>(M-N)\left(1-m_{g}\right)
$$

where $\bar{M}$ is the number of votes required to institute a moratorium, there will be a moratorium only in state $L$.

The effects of an anticipated moratorium in state $L$ on the equilibrium ex ante depend on how likely the realization of state $L$ is. We shall consider in turn situations in which the occurrence of state $L$ is unlikely ( $\lambda$ large) or very likely $(\lambda$ small $)$.

Ex ante equilibrium with high $\lambda$.-When state $L$ is highly unlikely, creditors do not worry much about the possibility of a moratorium in the event of a downturn. The expected return on lending at $t=0$ is then approximately the same as when there is no political intervention. An equilibrium with lending then exists in which the poor farmers' ex ante expected payoff is higher than in the equilibrium without political intervention.

Remarkably, in the rentier equilibrium, lenders may also be better off ex ante as a result of limited political intervention in state $L$. The reason is that for rentiers, renegotiation of debt contracts cannot be informed by the individual observation of the realized aggregate shock $v$. Indeed, if a limited moratorium reducing debt repayments to $\theta_{a}^{L}$ were implemented, then the political intervention in state $L$ would result in an ex ante optimal state-contingent debt contract whenever $\left(m_{g}+\right.$ $\left.m_{a}\right) \theta_{a}^{L}>m_{g} \theta_{a}^{H}$ and $\left[\lambda\left(m_{g}+m_{a}\right)+(1-\lambda) m_{g}\right] \theta_{a}^{H}>\left(m_{g}+m_{a}\right) \theta_{a}^{L}$. Thus, under such an anticipated limited moratorium, lenders would not choose to

\footnotetext{
${ }^{27}$ Note that moratoria would provide even stronger efficiency gains if the punishment for default was not just foreclosure but also a "debtor's prison." There seems to be little justification on efficiency grounds for debtor's prisons in our model.
} 
"opt out" of the political institution (e.g., by enforcing debt repayments in a different jurisdiction) even if they could.

In the wealthy farmer equilibrium, on the other hand, rich farmers are always (weakly) worse off than in the equilibrium without intervention since they can always achieve an optimal state-contingent repayment following renegotiation ex post. They would therefore always (weakly) prefer to opt out if they could.

Under our scenario, they are strictly worse off since under political intervention the repayment rate is still $D^{*}=\theta_{a}^{H}$ but they are repaid only in state $H$. On the other hand, their incentive to lend $\bar{W}-1$ instead of hiring laborers is strengthened by the fact that at $t=0$ the poor also anticipate a moratorium and demand higher wages equal to $R_{p}^{m}$, where ${ }^{28}$

$$
\begin{aligned}
R_{p}^{m}= & \lambda \cdot\left[\bar{\theta}^{H} k_{p}+m_{g}\left(\theta_{g}^{H}-\theta_{a}^{H}\right) k_{p} \theta_{g}^{H}\right]+(1-\lambda) \\
& \cdot k_{p}\left(\bar{\theta}^{L}+m_{b} \theta_{b}^{L}+m_{a}\left(\theta_{a}^{L}\right)^{2}+m_{g}\left(\frac{\theta_{g}^{L}}{k_{p}}\left[1+\frac{\theta_{g}^{L} k_{p}-\left(1-k_{p}\right)}{1+\theta_{b}^{L} k_{p}}\right]-\theta_{g}^{L}\right\}\right) .
\end{aligned}
$$

The rich now prefer to lend if and only if

$$
\lambda\left(m_{g}+m_{a}\right) \theta_{a}^{H} \geq \frac{\phi}{1+R_{p}^{m}}
$$

or

$$
R_{p}^{m} \geq \frac{\phi}{\lambda\left(m_{g}+m_{a}\right) \theta_{a}^{H}}-1 .
$$

Thus as long as conditions (12) and (13) hold, the equilibrium with moratoria is such that (i) rich farmers continue to lend at repayment terms $D^{*}=\theta_{a}^{H}$; (ii) no moratorium is voted in state $H$, with good and average types repaying their loans; and (iii) a moratorium is voted in state $L$.

Proposition 4. Equilibrium with political intervention.-When conditions (4), (6), (9), (8), (10), (12), (11), and (13) hold, there exists a wealthy farmer equilibrium at $t=0$ such that

1. all poor farmers become self-employed and borrow $k_{p}=N(\bar{W}-$ 1) $/(M-N)$ from rich farmers in return for a repayment $D^{*}=\theta_{a}^{H}$ at $t=1$;

2. no moratorium is voted in state $H$, but a moratorium is voted in state $L$;

3. bad poor farmers are foreclosed only in state $H$;

4. average and good poor farmers are never foreclosed.

${ }^{28}$ This expression is obtained by assuming that good poor types are liquidity constrained whether they repay $D^{*}$ or not (under a moratorium). 
Similarly, when conditions (3), (7), (5), (9), (11), and (12) hold, there exists a rentier equilibrium at $t=0$ that is identical to the wealthy farmer case except that $k_{p}=N \bar{W} /(M-N)$.

Proof. See the discussion above.

The equilibrium with political intervention dominates the one without political intervention in both ex ante and ex post productive efficiency. Ex post efficiency is improved in state $L$ by allowing average and bad type poor farmers to stay on their own farms and thus remain productive. Ex ante, the likelihood that state $L$ will occur is sufficiently small that it does not affect rich farmers' lending decisions, so that efficiency is not impaired.

As suggested in the Introduction, (limited) political intervention in a rentier equilibrium may also play a critical role in "completing" financial contracts that are constrained to be state-independent. Repayments cannot be made contingent on aggregate shocks in that equilibrium (even if one allows for renegotiation) because lenders cannot observe the realization of $v$. But majority voting on moratoria is able to "certify" the state of nature. If no majority in favor materializes, it becomes common knowledge that state $H$ has occurred (or that state $L$ has occurred if a majority in favor of a moratorium is formed).

Existence: numerical examples.-We have characterized the conditions for equilibrium both with and without political intervention. It remains to show that there are parameter values for which equilibrium exists. We found existence by expressing all our equilibrium conditions in GAUSS and then by searching for parameter values for which all the conditions were simultaneously satisfied. We report results only for an intervention via a moratorium in state $L$. (It is easy to show that when parameters are such that an equilibrium exists with anticipated political intervention, there is also an equilibrium with no intervention.)

Rentier equilibrium.-Recall that the interest rate is $\theta_{a}^{H}$. We assume in this example that a simple 50 percent majority is required to support a moratorium. Such a majority emerges in state $L$ but not in state $H$. Thus, in state $H$, bad poor types default, average poor types repay but have no resources left for additional investment, and good poor types invest and hire labor but are liquidity-constrained. When the moratorium is voted in state $L$, no one repays. The good poor invest and hire labor, and the average poor invest but do not hire labor. The rentiers lend all their endowment at $t=0$ and may see part of it returned with interest at $t=1$.

Values for which an equilibrium exists are $\bar{W}=1, \bar{k}=10, M / N=$ $2.1, m_{g}=.05, m_{a}=.25, \theta_{g}^{H}=13, \theta_{a}^{H}=3.6, \theta_{b}^{H}=.999, \theta_{g}^{L}=3.65$, $\theta_{a}^{L}=1.01$, and $\theta_{b}^{L}=.998$.

The equilibrium exists only if $\lambda \geq .93$. A high value of $\lambda$ is needed to satisfy the participation constraint for lenders. Table 1 shows, for each 
TABLE 1

\begin{tabular}{|c|c|c|}
\hline Parameter & Low & High \\
\hline$\theta_{g}^{H}$ & $7.67^{\mathrm{a}}$ & $17.6^{\mathrm{b}}$ \\
\hline$\theta_{a}^{\stackrel{H}{H}}$ & $31 / 3^{c}$ & $3.65^{\mathrm{d}}$ \\
\hline$\theta_{b}^{H}$ & $.427^{\mathrm{a}}$ & $1^{\mathrm{e}}$ \\
\hline$\theta_{g}^{L}$ & $3.6^{\mathrm{d}}$ & $7.66^{\mathrm{f}}$ \\
\hline$\theta_{a}^{L}$ & $1^{g}$ & $1.1^{\mathrm{h}}$ \\
\hline$\theta_{b}^{L}$ & 0 & $1^{\mathrm{e}}$ \\
\hline $\bar{W}$ & $.487^{\mathrm{a}}$ & $1.089^{\mathrm{h}}$ \\
\hline $\bar{k}$ & $9.455^{\mathrm{i}}$ & $\infty j$ \\
\hline$M / N$ & $2.01^{\mathrm{h}}$ & $2.111^{\mathrm{k}}$ \\
\hline$m_{g}$ & $.0448^{\mathrm{c}}$ & $.0778^{\mathrm{b}}$ \\
\hline$m_{a}^{8}$ & $.2487^{c}$ & $.527^{\mathrm{b}}$ \\
\hline \multicolumn{3}{|c|}{$\begin{array}{l}\text { NoTE. - The notes specify which constraint binds. } \\
\text { a Good poor vote for moratorium in state } H \text {. } \\
\text { a Labor demand exceeds number of bad, poor farmers. } \\
\text { ' Loans are unprofitable for rentiers. } \\
\text { d Good poor will not repay in state } L \text {. (This binds only } \\
\text { in the no-intervention model.) } \\
\text { c Bad poor will invest at } t=1 \text {. } \\
{ }^{\mathrm{f}} \text { Good poor vote against moratorium in state } L \text {. } \\
{ }^{\mathrm{g}} \text { Lower bound by assumption. } \\
{ }^{\mathrm{h}} \text { Average poor have } k>1 \text { at } t=1 \text {. } \\
{ }^{\mathrm{i}} \text { Good poor investments are constrained at } t=1 \text {. } \\
{ }^{\mathrm{j}} \text { Does not bind in rentier model. There is no rich labor } \\
\text { demand. }\end{array}$} \\
\hline
\end{tabular}

parameter, the range of values for which equilibrium continues to hold as the other parameters remain fixed in the base case.

These results correspond to our intuition about the model. For the rich to be willing to lend when moratoria are anticipated, the good state of the economy must be likely. For the interest rate to be pegged to the productivity of average types, these types must be relatively productive in the high state, and the good types must not be too numerous. Bad poor types must be sufficiently numerous to provide an ample supply of labor. The high productivity of good types in the high state affords the good poor with ample liquidity for investment; investment opportunities exist since $\bar{k}$ is relatively large. Interestingly, when $m_{a}$ is at its upper bound of .527 , the equilibrium holds for all $\lambda>.48$. The increased return to the rentiers makes lending sustainable when moratoria are anticipated, even when the low state of the economy is more likely than the high state. Note also that the ratio $M / N$ could be increased were the political system to require supermajorities to institute a moratorium.

Rich farmer equilibrium.-Our numerical example in this case used $\phi^{L}=\bar{\theta}^{L}$ and $\phi^{H}=\bar{\theta}^{H}$. We also found parameter values that were renegotiation-proof in the no-intervention case.

Values for which both the no-intervention and moratorium equilibria 
exist are $\bar{W}=10.5, \bar{k}=8, M / N=21.0, m_{g}=.085, m_{a}=.215, \theta_{g}^{H}=$ 12.7, $\theta_{a}^{H}=3.6, \theta_{b}^{H}=.999, \theta_{g}^{L}=3.65, \theta_{a}^{L}=1.01$, and $\theta_{b}^{L}=.3$.

The major distinction with the rentier equilibrium is that $M / N$ is much larger to provide labor supply for wealthy farmers who undertake substantial additional investment at $t=1$. To constrain the labor demand of the rich, $\bar{k}$ now cannot exceed 8.5. As a result of there being so many poor farmers, a supermajority rule of 88 percent would be required to block a moratorium in state $H .{ }^{29}$ The parameters are further constrained by the need to satisfy the renegotiation constraints, which do not apply to rentiers. The equilibrium does hold for a range of values about those given, but we omit a corresponding table to conserve space.

Ex ante equilibrium with low $\lambda$.-When a downturn is very likely and moratoria are anticipated, they give rise to credit rationing at $t=0$. Rich farmers or rentiers would rather not lend if they expect a moratorium. Lending at $t=0$ is then possible only if somehow a moratorium in state $L$ can be avoided.

Two ways of preventing a moratorium in state $L$ are (i) to lend to a limited number of poor farmers to guarantee that the number of debtors will not exceed $\bar{M}-1$ and (ii) to set sufficiently low repayment terms $D$ that the good poor farmers would vote against a moratorium even in state $L$.

We discuss these two options in turn. One difficulty with the first is that voting may not be restricted to debtors and creditors, so that the outcome of the vote will depend on how the remaining poor farmers vote. From the perspective of an agricultural laborer, a moratorium is always good news, since its main effect is to reduce the supply of labor. Thus laborers are always weakly in favor of moratoria. Therefore, restricting the number of borrowers is a feasible response only if agricultural laborers do not have the right to vote. In fact, voting rights were often restricted at the beginning of the nineteenth century (Keyssar 2000). Only landowners and sufficiently wealthy men were allowed to vote. In our model, restricting the franchise to those having capital, either endowed or borrowed, would improve ex ante efficiency. It would take out altogether the votes of agricultural laborers and thus make lending to $\bar{M}-1$ poor farmers sustainable.

Another means of making moratoria more difficult is to increase the size of the majority needed for enactment under direct democracy. Requiring more than $M-N$ votes to bring about a moratorium would suffice to reestablish credit markets without rationing. The same objec-

\footnotetext{
${ }^{29}$ In a working paper version of this paper, we were able to require only a 75 percent majority. This required having the rich have a distribution of good, poor, and bad types that matched the proportions of the poor.
} 
tive can be accomplished by shifting from direct democracy to a bicameral legislature with property interests overrepresented in one chamber.

The other way to ensure that a majority against moratoria exists ex post is to lower the repayment for some (or all) farmers to $D^{\#}$ so that the cost of repaying would be less important than the increased labor costs under a moratorium. In other words, $D^{\#}$ solves

$$
\left(\theta_{g}^{L}-D^{\#}\right) k_{p}=\left(1-k_{p}\right)+\frac{\theta_{g}^{L} k_{p}-\left(1-k_{p}\right)}{1+\theta_{b}^{L} k_{p}} .
$$

Good farmers borrowing at or below $D^{\#}$ would oppose a moratorium. If they were sufficiently numerous, a moratorium would be rejected by the voters. Under this scenario, ex post moratoria impose a constraint on lending terms but do not necessarily imply inefficient credit rationing ex ante.

Implementing a two-tier loan structure is not feasible with decentralized lending and uncertainty about the number of borrowers who will be good types. Free-riding will cause a two-tier structure to unravel. However, a two-tier structure could be supported if there were a single financial intermediary who would make the appropriate trade-off between increasing the probability of a moratorium and the benefit of obtaining $D^{*}$ rather than $D^{\#}$ from borrowers at the margin. The financial intermediary will consider making $r \in[M-N-\bar{M}+1, M-N]$ loans at $D^{\#}$. As $r$ increases, the probability of a moratorium falls. Let $q(r)$ denote the probability of a moratorium conditional on being in state $L$. Solely to simplify, we treat $r$ as continuous. Assume that the intermediary maximizes the wealth of the rich. The first-order condition for the intermediary's optimal $r$, denoted $r^{\#}$, is given by

$$
\begin{gathered}
\left\{\lambda\left(m_{a}+m_{g}\right)+(1-\lambda)\left[1-q\left(r^{\#}\right)\right] m_{g}\right\}\left(D^{*}-D^{\#}\right)= \\
-\frac{\partial q}{\partial r}(1-\lambda) m_{g}\left[D^{*}\left(M-N-r^{\#}\right)+D^{\#} r^{\#}\right] .
\end{gathered}
$$

The left-hand side of this expression is the expected cost to the creditors of shifting one unit of loan from the high interest rate to the low interest rate given the probability that no moratorium occurs in the low state. The first term on the right-hand side is the change in the probability of rejecting a moratorium in the low state brought about by an additional unit of loan. This is then multiplied first by the probability of the low state and then by the low-state return given that $r^{\#}$ loans are made at $D^{\#}$. When $M$ is large, standard law of large numbers arguments imply that $r^{\#}$ will be "slightly" larger than the number of loans, $(M-N-$ $\bar{M}+1) / m_{g}$, that would make the expected outcome of the election one vote short of enactment of a moratorium. The probability of a mora- 
torium, however, will be close to zero but strictly positive. Thus there is a small chance of observing a moratorium on the equilibrium path.

The equilibrium with an intermediary leads to greater ex post efficiency even when the effects of a moratorium are fully anticipated and the moratorium does not occur. The gain comes from good poor farmers who have borrowed more cheaply; they can use retained earnings to expand their farms at $t=1$.

This equilibrium has two interesting features. First, if the threat of a moratorium resulted in $D^{\#}<\theta_{a}^{L}$, then even average types would always repay their loans ex post. ${ }^{30}$ In this case, there is an additional ex post efficiency gain with the political institution of a moratorium. The threat of a moratorium allows average poor farmers to keep their farms. Second, the possibility of an ex post moratorium involves a transfer of rents to poor farmers both ex ante and ex post. Poor farmers also benefit ex ante since the threat of a moratorium in state $L$ can be avoided only by giving poor farmers better lending terms ex ante. Indeed, the loans made at $D^{\#}$ might even be unprofitable for the lenders. But it might pay the lenders to make these "political loss leaders" or buyouts if the losses were compensated by profits on the loans at $D^{*}$.

In the absence of a financial intermediary, a society faced with a threat of a moratorium at $t=1$ might adopt other legislation at $t=0$, even after endowments are known. First, the society could adopt a "constitutional" provision banning moratoria. Second, the society could pass a usury law, setting a maximum interest rate of $D^{\#}$. If the alternative to either of the measures were a complete collapse of credit markets, both measures would command unanimous support. As the poor, who are a majority, would prefer a usury law to a ban on moratoria, a usury law would prevail under universal suffrage.

In summary, when state $L$ is very likely to occur, moratoria do not occur on the equilibrium path. The threat of a moratorium undermines credit markets if there can be no discrimination among borrowers. Ex ante efficiency is also reduced if lenders discriminate via credit rationing. The threat of moratoria may lead to lower repayment rates, however, leaving ex ante efficiency unchanged and ex post efficiency improved.

\section{Conclusion}

With incomplete contracts, there is a case for governmental intervention in debt markets. First, an inefficiently large number of defaults may occur (even without aggregate uncertainty). Second, successful types among the poor stay underinvested because of liquidity constraints. We

\footnotetext{
${ }^{30}$ The fact that average types will repay for low values of $D^{\#}$ makes reduced terms more feasible for creditors.
} 
have shown how simple political institutions allow for intervention that may be beneficial not only ex post but also ex ante. In particular, majority rule may have the ability to "certify" when economic conditions merit debt relief. Thus the stay laws observed in the Panic of 1819 may be rationalized as an ex ante efficient response to large but rare negative macro shocks rather than as an inefficient form of expropriation that would deter future lending.

\section{References}

Alston, Lee J. "Farm Foreclosures in the United States during the Interwar Period.” J. Econ. Hist. 43 (December 1983): 885-903.

. "Farm Foreclosure Moratorium Legislation: A Lesson from the Past." A.E.R. 74 (June 1984): 445-57.

Balleisen, Edward J. "Vulture Capitalism in Antebellum America: The 1841 Federal Bankruptcy Act and the Exploitation of Financial Distress." Bus. Hist. Rev. 70 (Winter 1996): 473-516.

Bolton, Patrick, and Rosenthal, Howard. "The Political Economy of Debt Moratoria, Bailouts and Bankruptcy." In Defusing Default: Incentives and Institutions, edited by Marco Pagano. Baltimore: Johns Hopkins Univ. Press (for InterAmerican Development Bank), 2001.

Bolton, Patrick, and Scharfstein, David S. "A Theory of Predation Based on Agency Problems in Financial Contracting.” A.E.R. 80 (March 1990): 93-106.

_. "Optimal Debt Structure and the Number of Creditors." J.P.E. 104 (February 1996): 1-25.

Domowitz, Ian, and Tamer, Elie. "Two Hundred Years of Bankruptcy: A Tale of Legislation and Economic Fluctuations." Manuscript. Evanston, Ill.: Northwestern Univ., 1997.

Epple, Dennis, and Spatt, Chester. "State Restrictions on Local Debt: Their Role in Preventing Default.” J. Public Econ. 29 (March 1986): 199-221.

Freehling, William W. Prelude to Civil War: The Nullification Crisis in South Carolina, 1816-1836. New York: Harper and Row, 1966.

. The Road to Disunion. Vol. 1. Secessionists at Bay, 1776-1854. New York: Oxford Univ. Press, 1990.

Glaeser, Edward L., and Scheinkman, José A. "Neither a Borrower nor a Lender Be: An Economic Analysis of Interest Restrictions and Usury Laws." J. Law and Econ. 41 (April 1998): 1-36.

Hart, Oliver, and Moore, John. "A Theory of Debt Based on the Inalienability of Human Capital." O.J.E. 109 (November 1994): 841-79.

. "Default and Renegotiation: A Dynamic Model of Debt." Q.J.E. 113 (February 1998): 1-41.

Keyssar, Alexander. The Right to Vote: The Contested History of Democracy in the United States. New York: Basic Books, 2000.

Kroszner, Randall S. "Is It Better to Forgive than to Receive? Repudiation of the Gold Indexation Clause in Long-Term Debt during the Great Depression." Manuscript. Chicago: Univ. Chicago, Grad. School Bus., 1998.

North, Douglass C. The Economic Growth of the United States, 1790-1860. Englewood Cliffs, N.J.: Prentice-Hall, 1961.

Rohrbough, Malcolm J. The Land Office Business: The Settlement and Administration of American Public Lands, 1789-1837. New York: Oxford Univ. Press, 1968. 
Rothbard, Murray N. The Panic of 1819: Reactions and Policies. New York: Columbia Univ. Press, 1962.

Rucker, Randal R., and Alston, Lee J. "Farm Failures and Government Intervention: A Case Study of the 1930's." A.E.R. 77 (September 1987): 724-30.

U.S. Department of Commerce. Bureau of the Census. Historical Statistics of the United States: Colonial Times to 1970. Washington: Government Printing Office, 1975 . 